\title{
Effective prophylaxis of vertical HIV transmission despite late diagnosis of the mother's infection
}

\author{
Anna Stachowiak, Małgorzata Sobolewska-Pilarczyk, Małgorzata Pawłowska
}

Department of Pediatric Infectious Diseases and Hepatology, Collegium Medicum Bydgoszcz, Nicolaus Copernicus University in Torun, Provincial Hospital of Infectious Diseases, Bydgoszcz, Poland

\begin{abstract}
A newborn male born was admitted on the second day of life to the paediatric ward of the Provincial Observation and Infectious Hospital suspected of vertical human immunodeficiency virus (HIV) infection. In the mother's study, on the day of delivery, HIV markers were detected, which were confirmed on the following day by Western blotting. In the first day of life, the child was vaccinated against tuberculosis and hepatitis B. Before entering the infectious hospital ward, the newborn was breastfed several times until the second day of life. Laboratory tests showed elevated total bilirubin $(6.82 \mathrm{mg} / \mathrm{dl})$ with unincorporated bilirubin predominance $(6.4 \mathrm{mg} / \mathrm{dl})$. The viraemia of HIV RNA, which was undetectable, was evaluated by PCR. In accordance with the recommendations of the Polish AIDS Scientific Society, the newborn used triple antiretroviral therapy (ARV): zidovudine (ZDV), lamivudine (3TC), and nevirapine (NVP) in the following doses: ZDV $-2 \times 14 \mathrm{mg}$ for each day, 3TC $-2 \times 7 \mathrm{mg}$ for each day, and NVP $-2 \times 7 \mathrm{mg}$. Treatment with ZDV and 3TC was continued for four weeks, and NVP for the first two weeks of therapy. In the presented case, during the three- and six-month follow-up visits HIV viral RNA was undetectable, the CD4+ cell amount was normal, and there were no deviations in psychomotor development, indicating that the prophylaxis of vertical HIV was effective.
\end{abstract}

HIV AIDS Rev 2019; 18, 3: 228-231

DOI: https://doi.org/10.5114/hivar.2019.85950

Key words: vertical infection, HIV, newborn, prophylaxis.

\section{Introduction}

According to the National Centre for AIDS data, about 101 children infected with human immunodeficiency virus (HIV) live in Poland [1]. Over $90 \%$ of them were infected as a result of vertical transmission [2]. Most often, $65-75 \%$ are infected in the perinatal period. The most important risk factors include:

- no or unsuccessful antiretroviral treatment of the mother during pregnancy,
- the mother's disease or high HIV viral load above 10,000 copies $/ \mathrm{ml}$,

- premature rupture of the membranes,

- exposure of the foetus to the mother's blood and secretions,

- bloody amniotic fluid sucked from the airways,

- pre-term birth before the end of the $37^{\text {th }}$ week of gestation or childbirth after the $40^{\text {th }}$ week of gestation,

- termination of labour within four hours of the discharge of the pregnant women's foetal waters with detectable HIV viral load (over 50 copies $/ \mathrm{ml}$ ),
Address for correspondence: Dr. Anna Stachowiak, Department of Pediatric Infectious Diseases and Hepatology, Collegium Medicum Bydgoszcz, Nicolaus Copernicus University in Toruń, Provincial Hospital of Infectious Diseases, 12 św. Floriana St., 85-030 Bydgoszcz, Poland, e-mail: aniademuth@gmail.com
Article history:

Received: 17.03.2019

Received in revised form: 25.04.2019

Accepted: 26.04.2019

Available online: 20.04.2019
International Journal of HIV-Related Problems

HIV \& AIDS

R e v i e w 
- a ticking vessel,

- crotch,

- inflammation of the membranes and placenta,

- child's delivery to the mother's blood during Caesarean section, egg through injury.

Thanks to the protective role of the placenta, the risk of intrauterine HIV infection is lower and amounts to $5-10 \%$. The risk of newborn infections during breastfeeding is estimated at $5-10 \%$, but it increases to $40 \%$ when the feeding time is prolonged beyond six months [3-5].

The implementation of vertical HIV infection prevention reduces the risk of infecting a child to below $1 \%[2,6]$. The article presents a case of successful prophylaxis of vertical $\mathrm{HIV}$ infection despite the late diagnosis of this infection in the mother.

\section{Case description}

The newborn male born at 41 weeks of gestation I, by nature, with a birth weight of $3460 \mathrm{~g}$, rated at 10 points on the Apgar scale, was admitted on the second day of life to the Paediatric Ward of the Provincial Observation and Infectious Hospital, suspected of vertical HIV infection. Only hepatitis B and the syphilis were excluded in the child during the mother's pregnancy. In the study of the mother, on the day of delivery, HIV markers (current anti-HIV-1 and anti-HIV-2 antibodies and the current Ag p24 antigen) were detected, which were confirmed on the following day by Western blotting. On the first day of life, without knowing the mother's serological status, the child was vaccinated against tuberculosis and hepatitis B. Before entering the infectious hospital ward, the newborn was breastfed several times until the second day of life.

At the time of adoption, the boy's general condition was assessed as good. The child was viable, and in the physical examination, yellowing of the skin and sclera was found from the deviations. Laboratory tests showed elevated to- tal bilirubin $(6.82 \mathrm{mg} / \mathrm{dl})$ with unincorporated bilirubin predominance $(6.4 \mathrm{mg} / \mathrm{dl})$ (Table 1$)$. The viraemia of HIV RNA, which was undetectable, was evaluated by PCR. The CD4+ lymphocyte count was 1293 cells/ $\mu$ l (Table 1). Cytomegalovirus infection, HBV infection, and Toxoplasma gondii infection were excluded. Ultrasound of the abdominal cavity and peritoneal cavity of the head gave a correct picture.

In the child's mother, the value of HIV viral load on the second day after delivery was $5.01 \times 10^{3}$ copies $/ \mathrm{ml}$ and the CD4+ count was 501 cells/ $\mu$ lymphocytes (Table 1 ).

In accordance with the recommendations of the Polish AIDS Scientific Society, the newborn used triple antiretroviral therapy (ARV): zidovudine (ZDV), lamivudine (3TC), and nevirapine (NVP) in the following doses: ZDV $2 \times 14 \mathrm{mg}$ per day, 3TC $-2 \times 7 \mathrm{mg}$ per day, and NVP $2 \times 7 \mathrm{mg}$ (Tables 3-5). Treatment with ZDV and 3TC was continued for four weeks, and NVP for the first two weeks of therapy. During the stay in the ward the newborn baby was fed with modified milk and had a body weight of 400 grams by the $18^{\text {th }}$ day of life. During the treatment, haematological

Table 1. Laboratory tests for mother and child on admission to the hospital

\begin{tabular}{|c|c|c|}
\hline Laboratory test & Newborn & Mother \\
\hline PCR HIV RNA (copies/ml) & Undetectable & $5.01 \times 10^{3}$ \\
\hline $\begin{array}{l}\text { The number of CD4+ } \\
\text { lymphocytes (cells/ } \mu \mathrm{l})\end{array}$ & 1293 & 501 \\
\hline $\begin{array}{l}\text { HIV DUO ELISA (anti-HIV-1, } \\
\text { anti-HIV-2 + Ag p24) }\end{array}$ & Not performed ${ }^{*}$ & Positive \\
\hline Western blot HIV-1/HIV-2 & Not performed* & Positive \\
\hline Total bilirubin (mg/dl) & 6.82 & - \\
\hline Direct bilirubin (mg/dl) & 0.40 & - \\
\hline
\end{tabular}

have diagnostic value

Table 2. Studies performed in a child at week 1-2, 3, and 6 months of age

\begin{tabular}{l|c|c|c}
\hline \multirow{2}{*}{ Laboratory test } & \multicolumn{2}{|c}{ Monitoring of antiretroviral therapy } \\
\cline { 2 - 4 } & $\begin{array}{c}1-2 \text { weeks of age }- \\
\text { at hospital discharge }\end{array}$ & 3 months & 6 months \\
\hline PCR HIV RNA (copies/ml) & Undetectable & Undetectable & Undetectable \\
\hline The number of CD4+ lymphocytes (cells/ $\mu \mathrm{l})$ & 1293 & 2945 & 4415 \\
\hline Morphology & Without deviations & Without deviations & Without deviations \\
\hline ALAT $(\mathrm{U} / \mathrm{l})$ & 19 & 18 & 16 \\
\hline ASPAT $(\mathrm{U} / \mathrm{l})$ & 30 & 23 & - \\
\hline GGTP $(\mathrm{U} / \mathrm{l})$ & 62 & 27 & - \\
\hline Total bilirubin $(\mathrm{mg} / \mathrm{dl})$ & 0.42 & - & - \\
\hline Direct bilirubin $(\mathrm{mg} / \mathrm{dl})$ & 0.33 & - & 140 \\
\hline Glucose $(\mathrm{mg} / \mathrm{dl})$ & 76 & 93 & 0.21 \\
\hline Creatinine $(\mathrm{mg} / \mathrm{dl})$ & 0.37 & - & - \\
\hline
\end{tabular}


Table 3. Dosage of zidovudine in the prophylaxis of vertical transmission in newborns $[3,9]$

\begin{tabular}{l|c}
\hline Newborn born $\geq 35$ weeks of pregnancy & $\begin{array}{c}\text { Orally: } 4 \mathrm{mg} / \mathrm{kg} \text { every } 12 \text { hours for } 4 \text { weeks, or } \\
\text { Intravenous: } 3 \mathrm{mg} / \mathrm{kg} \text { every } 12 \text { hours for } 4 \text { weeks }\end{array}$ \\
\hline Premature baby $\geq 30$ and $<35$ weeks of pregnancy & $\begin{array}{c}\text { Orally: } 2 \mathrm{mg} / \mathrm{kg} \text { every } 12 \text { hours for } 2 \text { weeks, } \\
\text { later } 3 \mathrm{mg} / \mathrm{kg} \text { every } 12 \text { hours for } 2 \text { weeks } \\
\text { Intravenous: } 1.5 \mathrm{mg} / \mathrm{kg} \text { every } 12 \text { hours for } 2 \text { weeks, } \\
\text { later } 2.3 \mathrm{mg} / \mathrm{kg} \text { every } 12 \text { hours for } 2 \text { weeks }\end{array}$ \\
\hline Premature baby $<30$ weeks of pregnancy & Orally (non-preferred route of supply at this age): \\
& $2 \mathrm{mg} / \mathrm{kg}$ every 12 hours for 4 weeks \\
\hline
\end{tabular}

Table 4. Scheme of nevirapine administration in prophylaxis of vertical transmission in newborns [3, 9]

\begin{tabular}{l|l|c}
\hline $\begin{array}{l}\text { Birth } \\
\text { weight }\end{array}$ & $\begin{array}{l}\text { Administration hours for } \\
\text { nevirapine }\end{array}$ & Oral dose \\
\hline \multirow{2}{*}{$1.5-2 \mathrm{~kg}$} & $0-48$ hours & $8 \mathrm{mg}$ \\
\cline { 2 - 3 } & \begin{tabular}{l}
48 hours from the first dose \\
\cline { 2 - 3 }
\end{tabular} & 86 hours from the second dose \\
\hline $22 \mathrm{~kg}$ & $0-48$ hours & $12 \mathrm{mg}$ \\
\cline { 2 - 3 } & 48 hours from the first dose & $12 \mathrm{mg}$ \\
\cline { 2 - 3 } & 96 hours from the second dose & $12 \mathrm{mg}$ \\
\hline
\end{tabular}

Table 5. Diagram of triple antiretroviral therapy in the prophylaxis of vertical transmission in newborns $[3,9]$

\begin{tabular}{l|c}
\hline Zidovudine & Doses as in Table 2 \\
\hline Lamivudine & Orally: $2 \mathrm{mg} / \mathrm{kg}$ every 12 hours for 4 weeks \\
\hline Nevirapine & $\begin{array}{c}\text { Orally: } 2 \mathrm{mg} / \mathrm{kg} \text { every } 24 \text { hours for } 7 \text { days, } \\
\text { later } 2 \mathrm{mg} / \mathrm{kg} \text { every } 12 \text { hours for } 7 \text { days }\end{array}$ \\
\hline
\end{tabular}

parameters, glucose concentration, and hepatic and renal function indicators were monitored - no abnormalities were observed (Table 2). The concentration of total bilirubin on the day of discharge decreased to normal values $(0.42 \mathrm{mg} / \mathrm{dl})$ (Table 2). Control laboratory tests (PCR HIV RNA, CD4+ cell count, peripheral blood count, ALT and AST activity, bilirubin, lipid, glucose, creatinine, creatinine clearance, urinalysis) were performed after the child completed the first, third, and sixth month (Table 2). During all control visits, the boy's psychomotor development was assessed as normal, no deviations were observed in the physical examination, the laboratory results remained within the normal range, HIV viral load was undetectable, and the CD4+ cell count was more than 1200 cells $/ \mu \mathrm{l}$ (Table 2 ).

\section{Conclusions}

Prevention of vertical HIV reduces the risk of this infection from $25-30 \%$ to less than $1 \%$ [6]. Currently in Poland, in accordance with the Regulation of the Minister of Health of October 4, 2012 on standards of conduct and medical procedures for the provision of health services, perinatal care exercised over a woman during physiological pregnancy, physiological labour, puerperium, and neonatal care, during pregnancy two tests for HIV infection are to be carried out: the first by the $10^{\text {th }}$ week of pregnancy and the second one between the $33^{\text {rd }}$ and $37^{\text {th }}$ weeks of pregnancy [6-8]. If the tests are not performed during pregnancy, it is recommended that they are performed by the patient on admission to delivery or in the newborn. In the case described, the patient was not tested for HIV infection during pregnancy, and the blood for examination for this infection was taken on the day of delivery.

A pregnant woman diagnosed with HIV requires the implementation of antiretroviral treatment and procedures that minimise the risk of transmission of the virus from mother to child. These include, among others: avoiding groin incision and the use of ticks and obstetric vacuums $[2,6]$. The patient should be looked after by specialists in the following: infectious diseases, obstetrics, neonatology, and paediatrics. The goal of antiretroviral therapy is to achieve a full viral suppression (HIV viral load below 50 copies $/ \mathrm{ml}$ ). Assessment of HIV viral load in pregnancy is carried out monthly. The choice of how to terminate the pregnancy depends on the concentration of HIV viral load, and it should be carried out in the $34^{\text {th }}-36^{\text {th }}$ week of pregnancy. There is a relationship between HIV transmission in the mother and the risk of vertical transmission, and it is over $41 \%$ if the HIV viral load is higher than 100,000 copies/ml, while for HIV viral load less than 1000 copies $/ \mathrm{ml}$ the risk of rejection is less than $1 \%$. In the case of undetectable viral load, it is recommended to terminate the pregnancy by natural delivery, while for HIV viral load over 50 copies $/ \mathrm{ml}$, the solution should be performed in the $38^{\text {th }}$ week of pregnancy with an elective Caesarean section $[4,6]$. A pregnant woman diagnosed with HIV late or on the day of childbirth (before the baby is born) should be treated as having a high HIV viral load, and terminated pregnancy by scheduled Caesarean section [4-7]. In the present case, the patient gave birth by natural means, and according to the recommendations, delivery should take place through a planned Caesarean section $[4,6]$.

In the management of a newborn baby, $\mathrm{HIV}(+)$ procedures are different from those of a healthy mother [3, 8]. Children of HIV-infected mothers should be washed imme- 
diately after delivery, upper respiratory tract content should be removed, antiretroviral treatment should be started, modified breast milk introduced, and lactation suppressed in the mother; vaccination against tuberculosis should be delayed until HIV infection is excluded $[3,6]$.

The newborn should receive prophylactic antiretroviral therapy as soon as possible after delivery and no later than 48 hours after birth $[3,8,9]$. The decision to choose medication for prevention depends on the estimated risk of HIV transmission.

In children with uncomplicated births and mothers treated successfully with antiretroviral therapy, with low risk of vertical transmission of HIV, with only detectable HIV viral load, ZDV alone is used for four weeks in doses dependent on foetal age (Table 3) [3, 9].

In cases of increased risk of vertical transmission of HIV, in which the mother recieved anti-HIV treatment during pregnancy and the HIV viral load at 34-36 weeks of pregnancy is higher than 50 copies/ml, but lower than 1000 copies $/ \mathrm{ml}$, and the child was born via nature or prematurely, ZDV and three oral doses of NVP are used for four days for seven days (Table 4 ) $[3,9]$.

In the case of high risk of vertical transmission, when the mother was treated ineffectively or too briefly, and the value of HIV viral load in the 34-36 week of pregnancy exceeds 1000 copies/ml, or diagnosis was made shortly before delivery or postpartum, and the patient was not treated with antiretroviral medication in pregnancy, triple regimen is used: ZDV, 3TC, and NVP. ZDV and 3TC for four weeks, and NVP for two weeks (Table 5) [3, 9]. Treatment should be started as quickly as possible.

In the described case, the newborn was not washed immediately after delivery, and contact of the child with the mother for more than two hours was ensured ("skin on skin"), the newborn was placed to the breast and inoculated in the first day of life against tuberculosis. After diagnosing HIV infection in the mother on the second day of the child's life, triple antiretroviral therapy was used: ZDV, 3TC, and NVP.

All children of HIV+ mothers should have completed tests of HIV RNA and designated CD4+ cell counts, and studies should be carried out assessing the side-effects of antiretroviral therapy, including haematological parameters, hepatic and renal function indexes, blood glucose, and lipid levels in the following ages:

- $14^{\text {th }}-21^{\text {st }}$ days of life,

- 6-8 weeks of age: when the child has received two- or three-drug therapy,

- 1-2 months: if the newborn only received ZDV for four weeks or after delivery, no prophylaxis was included,

- 4-6 months [3].

Undetectable viral load and normal CD4+ lymphocyte count $(\geq 1200$ cells $/ \mu \mathrm{l})$ in studies performed at 2-3 weeks and 1-2 months of age allow the pre-exclusion of HIV infection in a child. The definitive exclusion of HIV infection in artificially fed children requires measurement of undetectable viral HIV and normal CD4+ count in the blood [3].
In this case, during the three- and six-month follow-up visits HIV viral RNA was undetectable, the CD4+ cell amount was normal, and there were no deviations in psychomotor development, indicating that the prophylaxis of vertical HIV was effective $[3,9,10]$.

The majority of HIV infections in children in Poland occur as a result of vertical transmission. Every pregnant woman should have a test for HIV infection. Recognition of this infection in a pregnant woman allows the implementation of AVR therapy, and thus the prevention of vertical transmission of this infection.

\section{Conflict of interest}

The authors declare no potential conflicts of interest with respect to the research, authorship, and/or publication of this article.

\section{References}

1. Official website Polish AIDS Society. Available at: https://aids.gov.pl/ hiv_aids/450-2-2/ (Accessed: 06.02.2019).

2. Redmond AM, McNamara JF. The road to eliminate mother-tochild HIV transmission. J Pediatr (Rio J) 2015; 91: 509-511.

3. Marczyńska M, Popieliska J, Ołdakowska A, et al. Zakażenie HIV u dzieci. In: Horban A, Podlasin R, Cholewińska G, et al. (eds.). Zasady opieki nad osobami zakażonymi HIV. Zalecenia PTN AIDS, Waszawa 2017; 114-134.

4. EACS Guidelines Version 8,1 October 2016; 13.

5. Vocks- Hauck M. HIV and Pregnancy. Therapy for mother and prophylaxis for neonates. In: Hoffmann C, Rockstroh JK (eds.). HIV 2015/2016. Medizin Fokus Verlag, Hamburg 2015/2016; 531-546.

6. Jankowska M, Lemańska M. Profilaktyka transmisji wertykalnej HIV u ciężarnej. In: Horban A, Podlasin R, Cholewińska G, et al. (eds.). Zasady opieki nad osobami zakażonymi HIV. Zalecenia PTN AIDS, Warszawa 2017; 48-54.

7. Niemiec T, Kotarski J, Radowicki S, et al. Rekomendacje Zespołu Ekspertów PTG w zakresie zapobiegania perinatalnej transmisji HIV. Ginekol Pol 2009; 80: 59-62.

8. Helwich E, Marczyńska M, et al. Zapobieganie zakażeniom HIV u noworodków. In: Adamska E, Bekiesińska-Figatowska M, Błaż W, et al. Standardy opieki medycznej nad noworodkiem w Polsce. Zalecenia Polskiego Towarzystwa Neonatologicznego. Wydanie II. Media-Press Sp. z o.o., Warszawa 2017; 246-250.

9. Panel on Antiretroviral Therapy and Medical Management of HIVInfected Children. Guidelines for the Use of Antiretroviral Agents in Pediatric HIV Infection. Last updated: November 27, 2017. Available at: http://aidsinfo.nih.gov/con- tentfiles/lvguidelines/pediatricguidelines.pdf.

10. Pulik P, Horban A. Leczenie antyretrowirusowe - monitorowanie i rozpoznanie leczenia antyretrowirusowego. In: Horban A, Podlasin R, Cholewińska G, et al. (eds.). Zasady opieki nad osobami zakażonymi HIV. Zalecenia PTN AIDS, Warszawa 2017; 69-73. 